\title{
全身性強皮症の食道狭窄に対する手術
}

\author{
東京都立大塚病院外科 奥 山 正 治 \\ 北里大学外科吉田宗紀阿曾弘一
}

\section{SURGICAL TREATMENT OF ESOPHAGEAL STRICTURE IN A PATIENT WITH PROGRESSIVE SYSTEMIC SCLEROSIS}

Tadaharu OKUYAMA

Department of Surgery, Metropolitan Ohtuka Hospital, Tokyo

Munenori YOSHIDA and Kohichi ASO

Department of Surgery, Kitasato University School of Medicine

膠原病のはとんどが㥛めて難治な疾患で複雑な臨床像を呈するものである．膠原病のう ちで最も消化管病変の多くみられるのは強皮症であり, その消化管病変のうちで食道が最 る高頻度に異常が認められる。この食道狭窄による焦下困難に対して, 原疾患には姑息的 であるとはい方，何らかの外科的治療を行ならことが，ときに必要となる、いるいろな多 くの合併疾患を有する本症に対して，この外科的治療を最も安全に，最も効果的に行なら には，如何なる方法がよいか竓論があるう。

我々は，最近本症の食道狭窄に対し，秋山らが行なった非開胸による食道拔去ののち， 胸骨後に胃を挙上し食道再建手術を行ない良好な結果を党た 1 例を経験した．そこで，本 症の食道狭窄に対し，これまでに如何なる手術方法が何例に行なわれ，その結果は如何で， あったかについて，文献的考察を加えて報告する。

\section{楮言}

全身性強皮症の食道病変に対して外科的治療が行なわ れることは比校的少ない(2)3)。

われわれは，63歳の女性にみられた全身性強皮症の食 道㹟窄に対して, 秋山ら ${ }^{2} か ゙$ 行った非開胸食道切除, 再 建術を行ない，良好な経過をたどった 1 例を経験した。 そこで，本症に対してこれまで行なわれてきた手術術式 について文献的考察を加えて報告する.

\section{症 例}

思者：63歳，主婦.

主培 : 曛下困難

現病歴：45歳頃，水分は容易に掑取できたが，固形物 捺取時に噮下障害が出見した。同じ頃より手関節がつっ ばり，皮届の光沢が著明となった，その後手関節のつっ ばりなとの皮厓症状は徐々に増強したが，䓵下障害は悪 化しなかった。 冬になると手指に Raynaud 現象を認め
ている。路和52年 5 月頃より徐々に瞕下障害が增強し， 昭和53年 6 月には，固形物はるとより水分の恸取す不可 能となり, 同年 6 月 3 日, 北里大学病院耳算咽侯科を受 診し，食道造影にて食道の狭窄を指摘された。これまで の1年間に $4 \mathrm{~kg}$ の体重減少がみられた。

既往歴：40歳頃，高血压 $(200 / 90 \mathrm{mmHg})$ を指摘 己 れ，それ以来降圧剤の投与を受けている。

家族歴：特記すべきことなし。

入院時所見：体格小，皮下脂肪少，血圧：190/70mm $\mathrm{Hg}$, 脈拍78/分整, 眼臉結膜筫血あり. 皮唐萎縮, 光次 あり， 口唇萎縮，放射状のしわみられ，開口障害あり。 顔面表情乏しく，Masked face (写事 1)，手関節部，手 指に運動制限あり，手背に teleangiectasia みられ，寒 冷時手指に Raynaud 現象あり.胸部正常，心音純，肺 は聪打診上異常なし、腹部は平坦で特に異常はみられな い. 


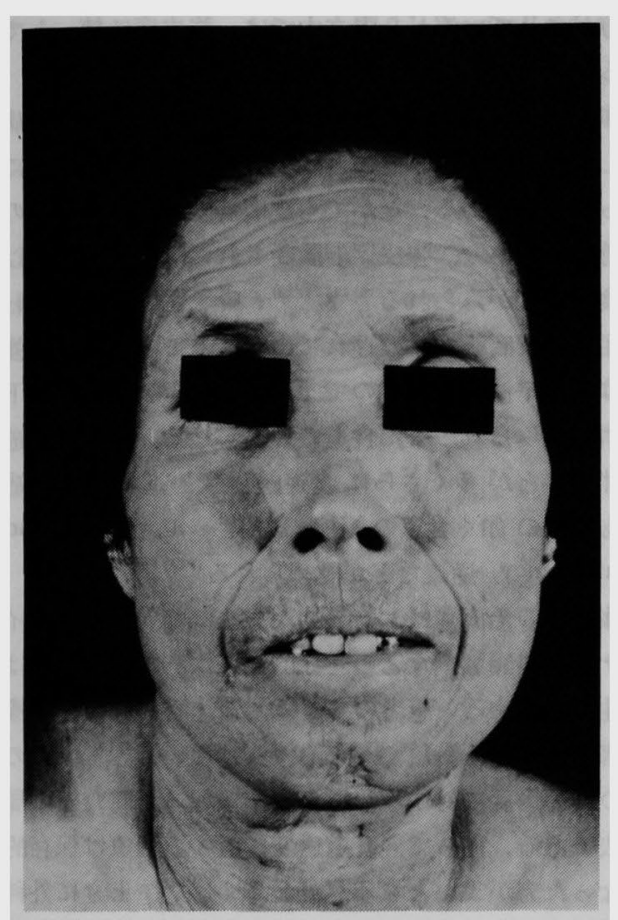

写卉163才, 主婦. 皮虐は萎縮し, 口居周囲に放 射状の毁譬を認める。

表 1 模查所見

\begin{tabular}{|c|c|c|c|}
\hline 血满一般 & & TIBC & $356 \mu \mathrm{g} / \mathrm{dl}$ \\
\hline RBC & 363 万 & IgG & $1500 \mathrm{mg} / \mathrm{dl}$ \\
\hline Hb & $8.8 \mathrm{~g} / \mathrm{dl}$ & $\operatorname{Ig} A$ & $500 \mathrm{mg} / \mathrm{dl}$ \\
\hline $\mathrm{Ht}$ & 28.39 & IgM & $93 \mathrm{mg} / \mathrm{dl}$ \\
\hline WBC & 3700 & $\beta_{1}$-c glob. & $160 \mathrm{mg} / \mathrm{dl}$ \\
\hline 血激化学 & & Renin & $3.1 \mathrm{mg} / \mathrm{dl}$ \\
\hline T. P & $7.6 \mathrm{~g} / \mathrm{dl}$ & CRP & $(-)$ \\
\hline$A / G$ & 1.6 & ESR & $34 \mathrm{~mm} / \mathrm{h}$ \\
\hline Alb & $56.0 \%$ & LE細胞 & $(-)$ \\
\hline$r \cdot$ glob & $18.3 \%$ & RA 細胞 & $(-)$ \\
\hline GOT & $18 \mathrm{mU} / \mathrm{ml}$ & 抗校沆体 & $(-)$ \\
\hline GPT & $11 \mathrm{mU} / \mathrm{ml}$ & 尿 検 査 & 正 常 \\
\hline$A \mathrm{~A} \cdot \mathrm{P}$ & $6 \mathrm{mU} / \mathrm{ml}$ & $\operatorname{PSP}(120$ 分) & $96 \%$ \\
\hline FBS & $89 \mathrm{mg} / \mathrm{dl}$ & ECG & W.N.L. \\
\hline BUN & $12 \mathrm{mg} / \mathrm{dl}$ & 呼吸機能 & \\
\hline Creatinin & $0.8 \mathrm{mg} / \mathrm{dl}$ & \% VC & $92 \%$ \\
\hline $\mathrm{Fe}$ & $62 \mu \mathrm{g} / \mathrm{dl}$ & FEV $\%$ & $80 \%$ \\
\hline
\end{tabular}

盒床模圼所見：（表 1）胸部 $\mathbf{X}$ 線上異常なく，食道造 影では食道下部に長さ $4 \mathrm{~cm}$ にわたる辺縁不整の狭窄が みられた. 食道は短縮し, その蝶動は低下し, 食道裂孔 ヘルニフがみられ，胃噴門部は開大していた（写䇆 2 ). 食道内圧測定で，ひきぬき時 E-C junction で高圧帯が 認められず, 全体の収縮能の减退が著しかった，食道内

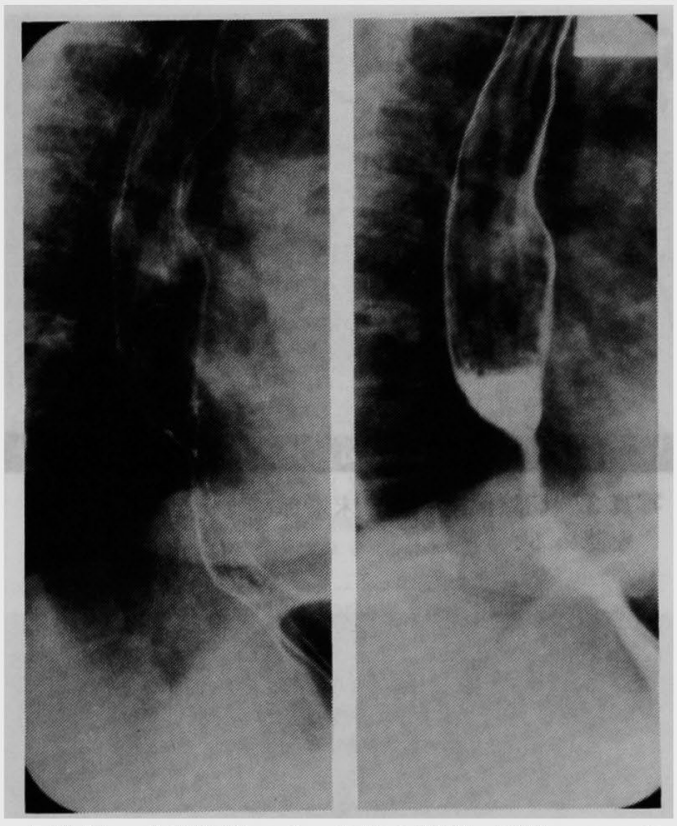

写克 2 食道造影にて, 食道の狭窄, 裂孔へルニフ 及び胃噴門部の開大がみられる。

視鏡所見は，門雪列より約 $30 \mathrm{~cm}$ の部位から，ほほ全周 性に狭窄がみられ，これに一致して白苔でおおわれた浅 い涄湯が認められた．潰瘍底及び辺緑などから数回生検 を行なったか，悪性像はなく，リンパ球や形質細胞な との細胞浸潤の強い急性炎症期の granulation tissue と necrotic tissue が認められた.

手術及び術後経過：これらの所見より全身性強皮症の 食道病変と診断し, 㗂下困難に対する治療として, 照和 53年 7 月 19 日非開胸的に食道を抜去し胸骨後経路にて胃 を頝部に吊り上げ食道胃吻合を施行した．術後経過は順 調で 3 週目より徐々に経口的に食事を開始した. 経口開

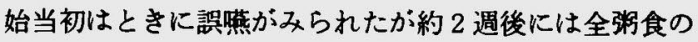
摂取も可能となった. 術後約 2 力月で退院し, 12 力月後 の現在, 噍下障害むなく, 体重も $2 \mathrm{~kg}$ の増加がみられて いる.

摘出标本所見：食道末端に带状のほぼ全周にわたる潰 痬 $(5.0 \times 2.0 \mathrm{~cm})$ がみられ，食道粘膜と 胃噴門部粘膜 との連続性は潰場によってほぼ断たれていた（写本了）. 影铰鏡的には，食道筋層特に内輪筋の線維化が著しく， 標本の口側断端から徐々に内輪筋の線維化がすすみ潰瘍 部では内輪筋の断裂がみられすべて線維でおき換ってい た．潰瘍は全体に UL-IIであったが，一部に UL-III たは UL-IVのところがみられ，それに一致して出血や 


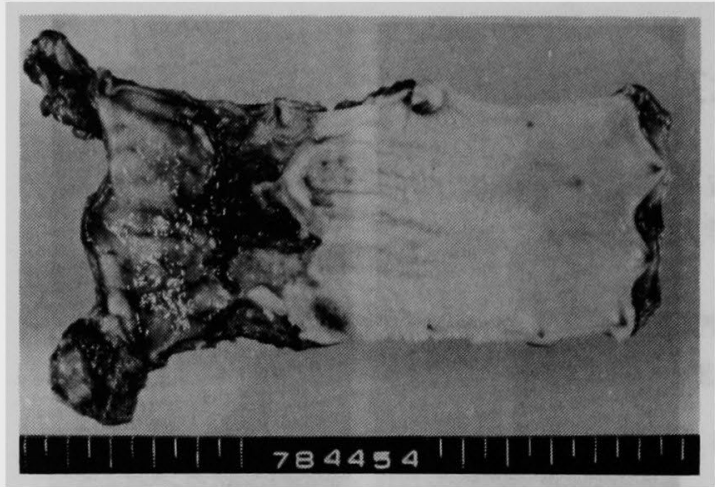

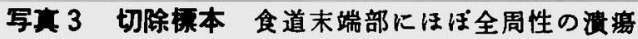
を認める。

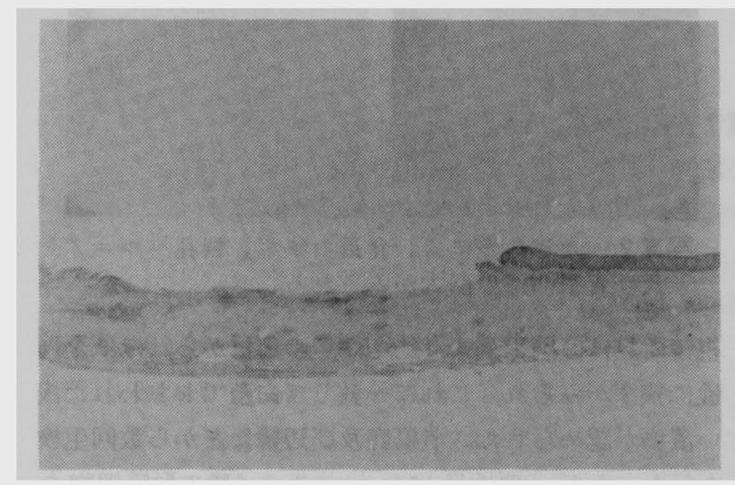

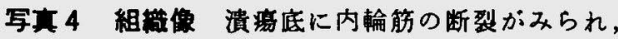
線維でおき換つている。

炎症細胞の浸㵎がみられた（写束 4 ）.

考宾

これまで, 強皮症の診断は臨床症状, 血清学的, 組織 病理学的諸検査の総合判断によって行なわれてきたが, 本症が難病対策の一環として厚生省の特定疾患に指定さ れ，その研究斑により作製された診断の基準がある゙。 われわれの症例の診断はこれに基ずいて行なった。強皮 症には, 2つの型があり ${ }^{5)}$ ， morphea と呼ばれる一つ は食道病変のない限局型のもので, 他の一つは, diffuse scleroderma（汎発性強皮症）又は, progressive systemic sclerosis(進行性全身性硬化症) と呼ばれる型で全身的采 統疾患であり， collagen disease の一つとして扱われて おり病因不明である゙．尚，強皮症の分類については古 くから種々の試みがなされており，銿口”，Tuffanelli" Barnet $\mathrm{t}^{9 !}$ の分類などがある。また，それぞれの文献に より scleroderma, diffuse scleroderma, progressive systemic sclerosis，強皮症，全身性硬化症などいろいろな用
い方がされてるか，本文中では，強皮症に統一して用 いる.

強皮症は，皮用の萎樎，硬化，色素沈着など皮席病変 として最初に現われることが多いが, 症状は全器官にわ たって多岐である．なかです皮庙病変についで多いのは 食道病変であり, 強皮症と沴断された時点で, 半数以上 に食道病変がみられる ${ }^{1011112) 13)}$. 無下困難として現われ る症状は皮后病変より遅れて出現することが多い．強皮 症は普通平滑筋を侵すので 食道下部2/3の 蟔動の低下又 は消失がみられ，また食道の短縮が起る．逆流生食道炎 を伴うことが多くさらに食道狭窄へと進さ．食道造影 です本症の如く食道の短縮, 裂孔へルニア, sphincter insufficiency, 逆流などが認められる111415)。

強皮症の治療には，特異的な方法はない、ステロイド やサリチル酸製剤などの対症的療法はあるが，病状は進 行性に経過する.患者の多くは，堅・心・肺などの機能 障害で死亡し，满足すべき治療法はない(1)16)17 。この疾 患の食道病変に対する治療も狭窄が起った時などの局所 療法である．従って，食道病変に対する治療は保存的に

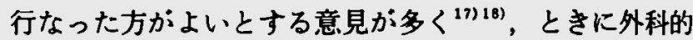

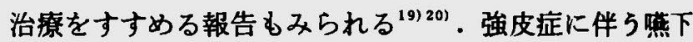
障害は，原疾患からくる食道壁の 粘膜下結合織の 線維 化, それに伴う平滑筋の神経細胞の著縮, 固有層中粘膜 層の増生，筋層の萎縮などによる螨動運動の低下のため とする説 ${ }^{101 \text { 15) 21) }}$ と逆流性食道炎から起る二次的なるのと する説 ${ }^{12) 22)}$ がありまたこの両者に関係するという議論 むある ${ }^{23)}$. いずれにしろ，その原因の一つに食道への逆 流が考えられるのでその治療法は絶えす続く逆流を最小 限におさえ，その酸性の内容物の中和をはかることにあ る.狭窄が起れば初期にはブジーで払張することができ るが，逆流が続く限りこれは一時的な効果でしかない。 逆流を防ぐ最す効果的な方法は手術による以外ないが， その適応として全身状態がく，比較的長期の子後が期 待される症例中，愁訴又は症状の強い者に限られる．し かし，食道穿孔や詥故による肺合併症のため死亡するこ とがあるから狭窄が高度でブジーなどにより払張されな い患者にとってはどうしても手術が必要となる。手術は 原疾患に対しては何の効果もない姑息的なものであり， 恰も門脈圧六進症の食道静脈瘤に対する出血防止のため の手術に似ている. 従って，手術は患者にとり，㹟窄な どの症状が改善され，しかす逆流を防止することの出来 る一番安全に行なえる方法が好ましい，これらの観点か らこれまで強皮症の食道狭菅に対して行なわれてきた手 
表 2 Surgical management of esophageal scleroderma

\begin{tabular}{|c|c|c|c|}
\hline Authers and Year & $\begin{array}{l}\text { No. of } \\
\text { patients }\end{array}$ & $\begin{array}{l}\text { No. of } \\
\text { operated } \\
\text { cases }\end{array}$ & Method \\
\hline Terracol \& Sweet (1958) & 1 & 1 & $\begin{array}{l}\text { stricture excision, } \\
\text { esophagogastrostomy ? }\end{array}$ \\
\hline Perdue \& Morris (1962) & 43 & 5 & $\begin{array}{l}\text { dilatatation for stricture (3) } \\
\text { exploratory operation (1) } \\
\text { jejunal transplantation (1) }\end{array}$ \\
\hline McLaughlin et al. (1971) & 2 & 2 & $\begin{array}{l}\text { esophagogastric resection, } \\
\text { esophagogastrostomy with vagotomy } \\
\text { and pyloroplasty (2) }\end{array}$ \\
\hline Brain (1973) & 10 & 10 & $\begin{array}{l}\text { repair hiatal hernia (6) } \\
\text { stricture excision (4) } \\
\text { jejunal transplantation ( } 3) \\
\text { colon transplantation (1) }\end{array}$ \\
\hline Akiyama et al. (1973) & 1 & 1 & $\begin{array}{l}\text { blunt dissection of the escphagus, } \\
\text { esophagogastrostomy via a posterior } \\
\text { mediastimal tunnel }\end{array}$ \\
\hline Pearson \& Henderson (1973) & 26 & 13 & $\begin{array}{l}\text { modified Belsey transthoracic hiatal } \\
\text { hernia repair (1) } \\
\text { Thal procedure ( } 1 \text { ) } \\
\text { Collis gastroplasty and modified } \\
\text { Belsey hiatal her'ma repair (11) }\end{array}$ \\
\hline O' Leary et al. (1975) & 2 & 2 & $\begin{array}{l}\text { Thal-Nissen procedure through the } \\
\text { left chest (2) }\end{array}$ \\
\hline Ornnger et al. (1976) & 53 & 11 & $\begin{array}{l}\text { combined Collis-Belsey operation (11) } \\
\text { dilatation of a peptic stricture (8) } \\
\text { pyloroplasty or pyloromyotomy (3) } \\
\text { gastrostomy (2) }\end{array}$ \\
\hline
\end{tabular}

街方法を文献的に検討してみた（表 2).

1958年, Terracol \& Sweet が, 食道狭窄を伴う強皮 症の 1 例に食道切除を行った報告がある゙の。手術法の詳 練は記述されていないか，㹟窄部を切除し食道胃吻合を 行なったと思われる。術後 6 年経過中燕下障害はみられ なかった。

1962年, Perdue \& Morris の報告'9)では, 1950年 から1960年にわたり Emory University Clinic で，43例 の強皮症中13例（30\%）に㬐下困難がみられ，この中の 5 例に外科的処居を行った。 3 例に狭窄部の搪張を行な い，1例に悪性腫瘍との鑑別のため試験手術を，他の 1 例に空腸移植を行ない満足すべき結果をえた。いずれの 症例についてい手街方法の詳細は述べられていない。

McLaughlin (1971) らは，2 例の強皮症の患者の下 部食道㹨害に対する手術について記載している ${ }^{25)}$ ，1例

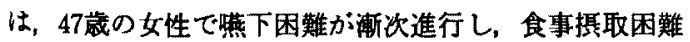
となったため胸腹切開で手術を行なった，食道㹟窄に裂 孔へルニアの合併が友とめられた。胃上部と下部食道 $6 \mathrm{~cm}$ を切除し，食道胃吻合を行なっだ。これに迷走神 释切除之幽門形成を付け加えた。術後蕉下障害はなく経 過したが，体重の増加はみられなかった。他の1例は， 43葴の女性て櫵下困難は食道抾張術に上り一時改善され
たが，食事摂取困難となり胃掼造設を行なった。6カ月 後に上腹部正中切開と右開胸で下部食道胃上部を $12 \mathrm{~cm}$ 切除し，食道胃吻合を 2 層 $3 〜 0$ 綃采結節搫合で行な いささらに迷走神経切除と幽門形成を行なった，術後嚾 下障害は消失し，体重は術前と変わらなかった。この理 由は食道胃切除のためか，原疾患のためかはっきりしな いと述へててい.

Brain (1973) は，食道裂孔ールニアと食道狭窄を伴 万强皮症の10例に外科的治療を行った ${ }^{26)}$. 裂孔へルニフ の修復を 6 例に，㹟窄部の切除と空渴又は結腸の移植を 4 例に行なった。裂孔へルニアの攸復だけでは結果が要 く，この中の 2 例にその後空腸移植を行なっている。 そ の他噴門筋切開や胃部分切除を行なった症例の释過もよ くなかった。腸管移植の 4 例中 3 例は㷛下困難が改善し、 2 例は 2 年及び 6 年释過して健在であり，他の 1 例は 9 年後に心筋硬塞で死亡した. 残りの1例は10年前に空腸 移植を行ない，5年経過後より蕉下障害が徐々にみら れ，現在移植空腸上部の食道に抎張がみられると述へて いる.

秋山ら（1973）は，強皮症による高度の食道㹟害に対 し，非開胸的に食道を报去したあと後䋛隔を通して䅡部 まで胃を挙上し，頝部食道胃吻合による1期的食道再建 


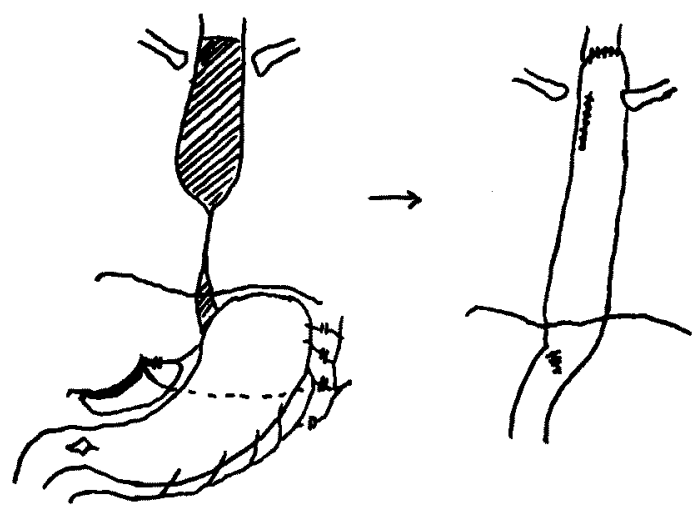

図 1 手術々式非開胸食道切除後, 後緃隔経路の 胃举上による食道再建術

を行ない满足すべき結果をえた 1 症例について報告して いる ${ }^{27)}$. その手術々式は，左穎部の皮切之左上腹部傍 正中切開に上り胸部食道を頊部及び 食道裂孔から blunt dissection にて非開胸下に切除しその後にできた後綎隔 のトンネルを通して胃を頚部切開創まで挙上し，頚部食 道胃吻合を行なら手技である28)29)（图1）。

Pearson and Henderson (1973) は, peptic esophagitis

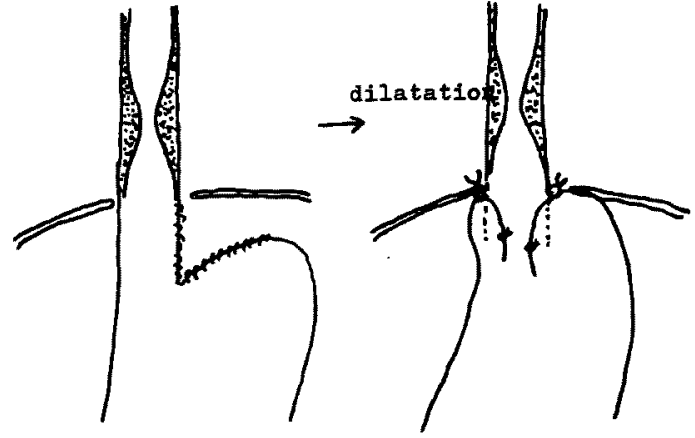

国 2 gastroplasty +Belsey hemia repair

による短食道の患者81人に Collis の gastroplasty と Belsey の hiatal hernia repair とを組み合わせた術式 を行ない，6カ月か 69 年の程過を追蹃し，その結果は 良好だったと述べている の患者が含まれている，まず㹟窄部の払張を行ない胃底 部を切開し食道の幅に胃管を作り，腹腔内人 $6 \mathrm{~cm}$ にな るよらにする。この胃管で作った新らたな食道の周囲へ Belsay の hiatal hernia repair を行ら手術法である゙” (図 2 ). 8 人の強皮症中，5例に食道狭乍がみられ， 他の3 例は食道裂孔一ルニフ術後逆流性食道炎のみられ
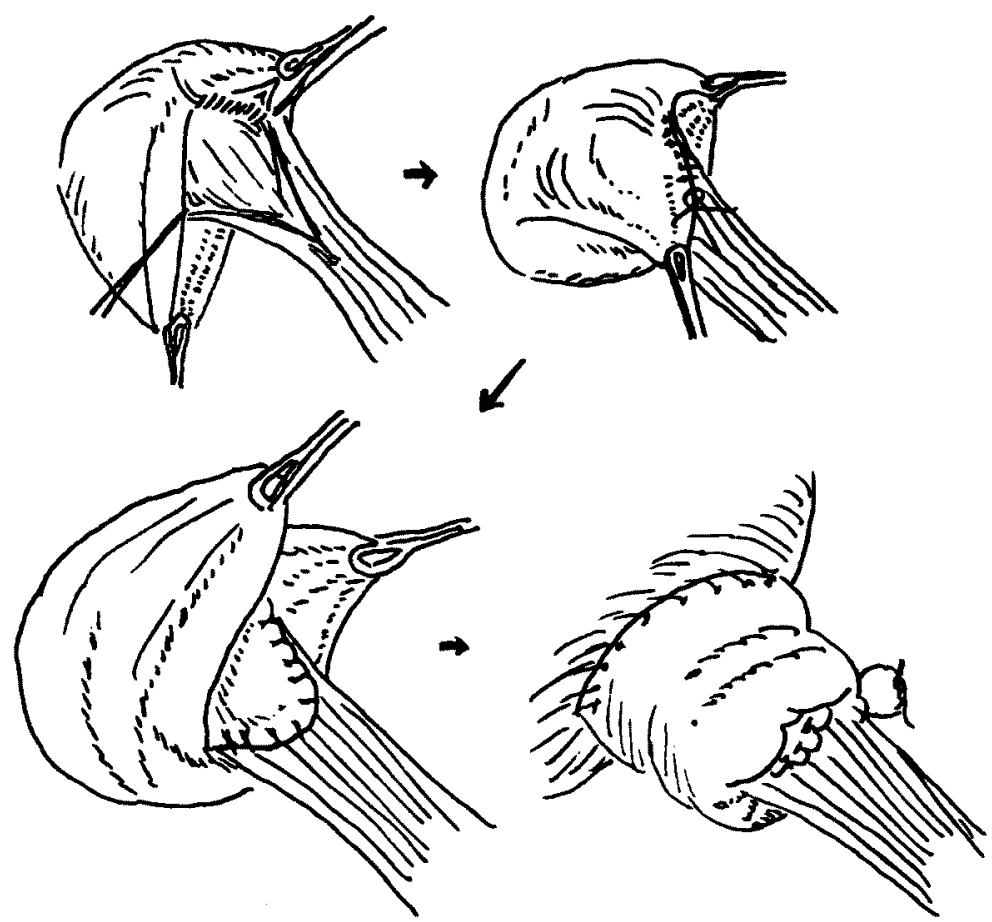

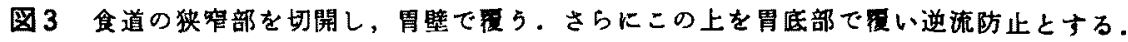


た症例である。この手衏を行なった結果，6例は症状が 消失し，X線上这流むなく経過しているが, 残りの 2 例 中, 1 例は強皮症の進行例で手術中冠動脈閉塞のため死 亡, 他の 1 例む强皮症の進行例で術後のX線や内視鏡に よる検査ではへルニフの再発や逆流性食道炎はみられな かったが，逆流の症状と蕉下障害が綂き，術後15力月で 腸閉塞のため死亡した。 その後の Henderson and Pearson の報告")では，強皮症の同術式に上る症例は13人に增 之，6〜22力月 (平均13.5力月) の経過観察で上記死亡 2 例を除く 11 例中 9 例にX線上へルニフの再発及び逆流 は認められず满足すべき結果だとしている。

O'Leary ら（1975）は，強皮症に伴な5食道狭窄の 2 症例飞 Thal-Nissen patch and fundoplication の方法で 手街を行ない，術後䈍下障害もなく22カ月及び14カ月 経過した症例を報告しているる22)．その方法は左開胸に て，図3に示す如く，まず㹟窄部を切開し胃壁で覆った あと Nissen の fundoplication を加六逆流を防止する 方法である ${ }^{32)}$. 1 例恃食道形成に迷走神経切除，ドレナ 一シ手術を行なった後10カ月経過し，燕下困難が再度続 いた64藏の女性であり, 他の1例は，52歳の女性で，十 二指腸溞場のため迷走神経切除、ドレナージ手術を受け た媵，䈍下困難が起こり，104ポンドから64ボンドまで 体重減少がみられた。强皮拝に上る食道病变の他, 小 鹤にも病変が認められた。2週間の高カロリ一輸液後 Thal-Nissen の手術を行ない, 術後踣下障害むみられず, 14カ月後体重は109ポンドになった。

Orringer $ら(1976) は$, 強皮症53症例についてその病 状と食道透視及び食道機能模査の結果を検討し，その中 で8例の狭窄を含む山症例に，Collis-Belsey の手術を 行ない，全例に逆流が消失したと報告している ${ }^{12)}$ ，その 術式は Pearson and Henderson と同じ法で Collis の gastroplasty $K$ Belsey $の$ Mark IV hiatal hernia repair を加えたものである ${ }^{331}$. 術後 3〜15力月の追跡結果は, X線上 5 例で狭窄が完全に改善し，3例で部分的によく なったと述べている。

この他，日本の文献では，同し胗原病に属する Systemic lupus erythematosus $の$ 食道㹟窄に対し，食道切除並 びに食道胃物合を胸骨後に再建した報告がみられる

以上が、これまでの文献にみられた强皮症の食道㹨窄 に対する手術方法であるが，強皮症に特有な術式といら

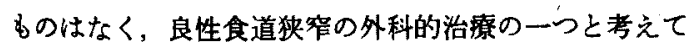
行なわれてきたよらである。これらの方法をみると，強 皮症にしばしばみられる食道病変を䍜患食道とともに切
除する方法と強皮症の食道狭窄が reflux に上る二次的 なるのに起因すると考光，O'Leary らが行っだ Nissen の逆流防止の方法をとりいれた手術衍式の二つに大別さ れる。後者は Pearson \& Henderson らの方法と相通ず るむのがある。いずれにしろ，原疾患の治療には関係の ない蛄息的な方法であるから，いろいるな合併疾患を有 する本症に対しては，特に手術が安全に行なえること， 通過障害が改善され，その結果のよいことが大切であ る.

$$
\text { われわれは，開胸による手術侵基の過大2127) を考之， }
$$
秋山らの行った非開胸による食道技去術を選んだ。しか し, Pearson P O'Leary Бの食道切除を行なわない方 法などといずれが手術侵嶈が過大であるかの検討を含 め,どの術式がすぐれているか，今後に残された課題と 思われる。独特な臨床症状を呈し，また極めて䗅慢な释 過を示す本症が，蓓下困難の根底にあることを考虑した 一番よい街式が確立されることが望まれる。

\section{結 論}

63瓷の女性の強皮症にとるな5食道㹟㺘に対し，非開 胸による食道抜去ののち，胸骨後に胃を举上し食道再建 手術を行ない良好な結果をえた，强皮症の食道狭窄に対 して,これまで如何なる手街法が行なわれてきたかにつ いて文献的考察を加え報告した.

\section{文献}

1) Schackelford, R.T.: Surgery of the alimentary tract vol. 1 Esophagus, W.B. Saunders Company, 1978.

2) Akiyama, H., Kogure, T. and Itai, Y.: Esophageal reconstruction for stenosis due to diffuse scleroderma. Arch. Surg., 107: 470-472, 1973.

3) Henderson, R.D. and Pearson, F.G.: Surgical management of esophageal scleroderma. J. Thorac. Cardiov. Surg., 66: 686-692, 1973.

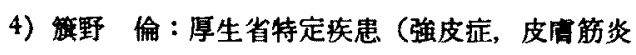
及び多発性筋炎調查研究斑) 昭和 48 年度研究業 樍, 1974.

5) Farmer, R.G., Gifford, R.W. and Kines, E.A.: Prognostic significance of Raynaud's phenomenon and other clinical characteristics of scleroderma: A study of 271 cases. Circulation, 21: 1088-1096, 1960.

6) Poirien, T.J. and Rankin, G.B.: Gastrointestinal manifestations of progressive systemic 
scleroderma based on a review of 364 cases. Am. J. Gastroenterol., 58: 30-39, 1972.

7）樋口謙太郎：日本皮展科全書，第 5 巻，金原出 版, 1954 .

8) Tuffanelli, D.L. and Winkelmann, R.K.: Systemic scleroderma. A clinical study of 727 cases. Arch. Derm., 84: 359-371, 1961.

9) Barnett, A.J.: Scleroderma (Progressive systemic sclerosis). Charles C. Thomas Publisher, 1974.

10) Treacy, W.L., Baggenstoss, A.H., Slocumb, C.H., et al.: Scleroderma of the esophagus. A correlation of histologic and physiologic findings. Ann. Intern. Med., 59: 351-356, 1963.

11）斎藤 弘, 粒良邦产: 膠原病と消化管, 臨床 免疫，6:593-616，1974.

12) Orringer, M.B., Dabich, L., Zarafonetis, C.J. D., et al. : Gastroesophageal reflux in esophageal scleroderma: Diagnosis and implications. Ann. Thorac. Surg., 22: 120-130, 1976.

13) D'Angelo, W.A., Fries, J.F., Masi, A.T., et al.: Pathologic observations in systemic sclerosis (scleroderma). Am. J. Med., 46: 428-440, 1969.

14) 野口真利, 林 正孝, 岡本真郎他: PSS におけ 万食道病変のX線診断, 臨床放射線, $23: 43$ $50,1978$.

15) Atkinson, M. and Summerling, M.D.: Oesophageal changes in systemic sclerosis. Gut, 7: $402-408,1966$.

16）营原光雄：強皮症の対策と治療，現代医療，8: 1095-1098, 1978.

17) Rob, C. and Smith, R.: Clinical Surgery. Butterworth and Co. Ltd., 1965.

18) Olsen, A.M., O'Leary, P.A. and Kirklin, B.R.: Esophageal lesions associated with arteriosclerosis and scleroderma. Arch. Intern. Med., 76: 189-196, 1945.

19) Perdue, G.D. and Morris, A.J.: Surgical manifestations of scleroderma. Surg. Gynec. Obstet., 115: 745-748, 1962.

20) Payne, W.S.: Surgical treatment of reflux esophagitis and stricture assoiated with permanent incompetence of cardia. Mayo Clin. Proc., 45: 553-558, 1970.

21) Bockus, H.L.: Gastroenterology, vol. I. W.B. Saunders Company, 1975.

22) O'Leary, J.P., Hollenbeck, J.I. and Woodward, E.R.: Surgical treatment of esophageal stricture in patients with scleroderma. Am. Surg., 41 : 131-135, 1975.

23) Leinwand, I., Duryec, A.W. and Richter, M.N.: Scleroderma based on a study of over 150 cases. Ann. Intern. Med., $41: 1003-1009$, 1954.

24) Terracol, J. and Sweet, R.H.: Disease of the esophagus. W.B. Sauders Company, 1958.

25) McLaughlin, J.S., Roig, R. and Woodruff, M.F.A.: Surgical treatment of strictures of the esophagus in patients with scleroderma. J. Thorac. Cardiov. Surg., 61:641-645, 1971 .

26) Brain, R.H.F.: Surgical management of hiatal herniae and esophageal strictures in systemic sclerosis. Thorax., 28: 515-520, 1973.

27）秋山洋、木暮 喬, 板井悠二：汎発性登皮症 のが食道㹟窄に対する非開胸食道切除再建術 式, 外科, $35: 661-665,1973$.

28) 秋山 洋, 佐藤靖雄, 高橋文夫他 : 食道全摘出 による 1 期的唡頭胃吻合術, 手術, $27: 1-5$, 1973.

29）秋山洋，桧山讙，宮菌 光：食道抜去の手 技と適応，手術，30：1123-1126，1976.

30) Pearson, F.G. and Henderson, R.D.: Experimental and clinical studies of gastroplasty in the management of acquired short esophagus. Surg. Gynecol. Obstet., 136: 737-744, 1973.

31) Pearson, F.G., Langer, B. and Henderson, R.D.: Gastroplasty and Belsey hiatus hernia repair. J. Thorac. Cardiov. Surg., 61: 50$63,1971$.

32) Nissen, R.: Gastropexy and fundoplication in surgical treatment of hiatal hernia. Am. J. Dig. Dis., 6: 954-961, 1961.

33) Orringer, M.B. and Sloan, H.: An improved technique for the combined Collis-Belsey approach to dilatable esophageal strictures. J. Thorac. Cardiov. Surg., 68: 298-302, 1974.

34）竹林淳, 浅田健葴：膠原病に上る 食道病变, 日本医事新報，2666：37-40，1975. 